\title{
The cadmium-mercaptoacetic acid complex contributes to the genotoxicity of mercaptoacetic acid-coated CdSe-core quantum dots
}

This article was published in the following Dove Press journal:

International Journal of Nanomedicine

23 May 2012

Number of times this article has been viewed

\section{Weikun Tang' \\ Junpeng Fan' \\ Yide $\mathrm{He}^{\prime}$ \\ Bihai Huang ${ }^{2}$ \\ Huihui Liu' \\ Daiwen Pang ${ }^{2}$ \\ Zhixiong Xie'}

'College of Life Sciences, ${ }^{2}$ College of Chemistry and Molecular Sciences, Wuhan University, Wuhan, People's Republic of China
Correspondence: Daiwen Pang College of Chemistry and Molecular Sciences, Wuhan University, Wuhan, 430072, People's Republic of China

Tel +86276875 6759

Email dwpang@whu.edu.cn

Zhixiong Xie

College of Life Sciences, Wuhan

University, Wuhan, 430072,

People's Republic of China

Tel +86 2768754533 ext 8I

Fax +8627 68752560

Email zxxie@whu.edu.cn

\begin{abstract}
Quantum dots (QDs) have many potential clinical and biological applications because of their advantages over traditional fluorescent dyes. However, the genotoxicity potential of QDs still remains unclear. In this paper, a plasmid-based system was designed to explore the genotoxic mechanism of QDs by detecting changes in DNA configuration and biological activities. The direct chemicobiological interactions between DNA and mercaptoacetic acid-coated CdSecore QDs (MAA-QDs) were investigated. After incubation with different concentrations of MAA-QDs $(0.043,0.13,0.4,1.2$, and $3.6 \mu \mathrm{mol} / \mathrm{L})$ in the dark, the DNA conversion of the covalently closed circular (CCC) DNA to the open circular (OC) DNA was significantly enhanced (from $13.9 \% \pm 2.2 \%$ to $59.9 \% \pm 12.8 \%$ ) while the residual transformation activity of plasmid DNA was greatly decreased (from $80.7 \% \pm 12.8 \%$ to $13.6 \% \pm 0.8 \%$ ), which indicated that the damages to the DNA structure and biological activities induced by MAA-QDs were concentration-dependent. The electrospray ionization mass spectrometry data suggested that the observed genotoxicity might be correlated with the cadmium-mercaptoacetic acid complex (Cd-MAA) that is formed in the solution of MAA-QDs. Circular dichroism spectroscopy and transformation assay results indicated that the $\mathrm{Cd}-\mathrm{MAA}$ complex might interact with DNA through the groove-binding mode and prefer binding to DNA fragments with high adenine and thymine content. Furthermore, the plasmid transformation assay could be used as an effective method to evaluate the genotoxicities of nanoparticles.
\end{abstract}

Keywords: genotoxicity, MAA CdSe quantum dots, cadmium-MAA complex, transformation assay, DNA

\section{Introduction}

Currently, the use of quantum dots (QDs) in biological applications has received considerable attention because of their advantages over conventional fluorescent dyes. Because of unique optical and electrical properties such as brightness, photostability, narrow emission and broad absorption, ${ }^{1-3}$ quantum dots have been used for labeling neoplastic cells, peroxisomes, DNA in vitro, ${ }^{4-6}$ and fluorescence imaging in vivo. ${ }^{7}$ In addition to biomedical labeling in vitro and imaging in vivo, applications in fields such as medicine and industry ${ }^{8,9}$ have also been demonstrated.

As the biological applications of nanoparticles have become widely accepted, the need for understanding the potential toxicity of QDs has become an important priority. Although there have been several studies investigating the toxicity of QDs to both cell cultures and live animals because of the inherently toxic elements of the QD core (eg, cadmium, selenium) and QD coatings, ${ }^{10-12}$ the potential genotoxicity of QDs was masked by their cytotoxicity; therefore, little is known about the direct interactions between QDs and DNA. 
The maintenance of biological activity of DNA is considered to be an essential requirement when using nanoparticles for in vitro labeling of DNA or for in vivo imaging. However, there is no quantitative method established to evaluate the biological effects of nanoparticles on DNA. The loss of biological activity of plasmid DNA, arising from exposure to QDs, should be systematically examined to obtain the complete toxicological information of QDs. Thus, in this paper, the plasmid-based transformation assay system, which is a quantitative analysis method, was established to evaluate the genetic effects of nanoparticles used in biological applications.

Furthermore, although the mechanism for the toxicity of QDs due to the effects of their single inherent chemical compositions (eg, cadmium, surface coating) has been reported, ${ }^{10,11}$ the coeffects of multicomponents have largely been overlooked, as QDs with surface functionalities such as the mercapto (-SH) groups, mercaptoacetic acid-QDs (MAA-QDs), and glutathione-QDs (GSH-QDs) have widely been accepted for use in biological applications. ${ }^{13,14}$ It has been demonstrated that the binding of $\mathrm{Cd}$ to sulfide, thiol groups, and sulfur-rich complex compounds could result in cadmium toxicity, ${ }^{15}$ and the ability of the cadmium-metallothionein complex to cause DNA damage has been described. ${ }^{16}$ However, ligand methyl mercaptoacetate, as a chelating agent, forms the $\mathrm{CdL}_{2}$ complex with cadmium chloride in water solutions at any molar ratio, ${ }^{17}$ and the interaction between DNA and the $\mathrm{CdL}_{2}$ complex is currently unclear.

In the present study, the genotoxic effects and mechanism of QDs have been systematically investigated. Changes in DNA configuration and biological activities were detected by agarose gel electrophoresis and genetic transformation. Electrospray ionization-mass spectroscopy (ESI-MS) was performed to detect the Cd-MAA complex in the solution of MAA-QDs. The in vitro interaction of the Cd-MAA complex with DNA was investigated employing sensitive techniques. The ethidium bromide (EtBr) displacement was investigated using fluorescence spectroscopy to elucidate the binding mechanism of the Cd-MAA complex with DNA. Circular dichroism (CD) was employed to assess whether DNA undergoes conformational changes as a result of Cd-MAA complex formation. Here, we report a quantitative analysis method for evaluating the genotoxicity of nanoparticles and a novel genotoxic mechanism of MAA-coated CdSe QDs. Our results suggest that the Cd-MAA complex formed in the solution of MAA-coated CdSe QDs has an innate tendency to damage plasmids with a high AT content or an AT-rich region through a groove-binding mode, and therefore affect the biological activity of DNA.

\section{Materials and methods Chemicals}

Calf-thymus DNA (CT-DNA) and ethidium bromide (EtBr) were obtained from Sigma-Aldrich (St. Louis, MO). Mercaptoacetic acid and cadmium chloride were purchased from Sinopharm Chemical Reagent Co, Ltd (Shanghai, China). The nano- $\mathrm{TiO}_{2}$ used in this work was obtained from Degussa (P25; Degussa, Essen, Germany). Fullerenes $\left(\mathrm{C}_{60}, 98 \%\right)$ were purchased from Sigma-Aldrich (St Louis, $\mathrm{MO})$. The core-shell CdSe/ZnS QDs used in this work were kindly provided by Wuhan Jiayuan Quantum Dots Co, Ltd (Wuhan, China). The QDs were coated with mercaptoacetic acid (MAA) according to the method reported by Wu et al. ${ }^{18}$ The octylamine-modified polyacrylic acid-coated CdSe/ ZnS QDs were prepared according to the method reported by $\mathrm{Wu}$ et al. ${ }^{6}$ All aqueous solutions were prepared using ultrapure water.

\section{Cloning of double-stranded DNA of varying percentages of GC base pairs}

The pMD-18T cloning vector (guanine and cytosine [GC] content $=50 \%$, TaKaRa Biotech Co, Dalian, China) was used for DNA cloning. Plasmid Tgc $(\mathrm{GC}$ content $=59.55 \%)$ and plasmid Tat $(\mathrm{GC}$ content $=41.5 \%)$ were constructed by inserting different DNA fragments into pMD-18T cloning vector. A 2688-bp fragment (corresponding to nucleotide positions from 4754 to 7442 in the Halobacterium $s p$. NRC-1 sequence, GC content $=69.1 \%$ ) was amplified using PCR with the forward primer F-Tgc (5'-TCACCCGCTGTTACGGCACC-3') and the reverse primer R-Tgc (5'-TCAGGGGCTACATCGGCACC-3'). A 2688-bp fragment (corresponding to nucleotide positions from 5022 to 7710 in the Saccharomyces cerevisiae sequence, $\mathrm{GC}$ content $=33.0 \%$ ) was amplified using PCR with the forward primer F-Tat (5'-CCTTGTTCTACTGACAGGATGG-3') and the reverse primer R-Tat (5'-TCTCGTTGGTTTGCGATTAT-3'). The products from the PCR were separated using agarose gel electrophoresis, excised, purified using an Agarose Gel DNA Extraction Kit (TaKaRa Biotech, Dalian, China) and cloned into the pMD-18T vector. After the corresponding positive clones were selected, plasmid DNA was prepared from a single clone using the kit from Tiangen (Beijing, China). The quantity and purity of the DNA were verified by measuring $A_{260}$ and $A_{280}$. 


\section{Detection of DNA strand breaks}

The pUC18 plasmid ( $>70 \%$ supercoiled) was purchased from TaKaRa Biotech. DNA single-strand breaks were detected by the conversion of double-stranded covalently closed circular DNA (CCC form) to double-stranded opened circular DNA (OC form). DNA incubations were performed in $1.5 \mathrm{~mL}$ micro-centrifuge tubes. After the DNA incubations, the DNA samples were electrophoresed on a $1 \%$ agarose gel in $1 \times$ TAE buffer $(40 \mathrm{mmol} / \mathrm{L}$ Tris-acetate and $1 \mathrm{mmol} / \mathrm{L}$ EDTA at $\mathrm{pH}=8.0$ ) at $140 \mathrm{~V}$ for $40 \mathrm{~min}$. After staining with ethidium bromide, the gel was photographed using a Syngene camera under an ultraviolet illuminator. Each experiment was repeated at least three times. Scanning densitometry results from a single representative gel picture are shown in this study.

\section{Effects of different concentrations of MAA-QDs on plasmid DNA}

In a $200 \mu \mathrm{L}$ reaction mixture (ultrapure water), $833 \mathrm{ng}$ plasmid pUC18 DNA was incubated with QDs (final concentration, $3.6 \mu \mathrm{mol} / \mathrm{L}, 1.2 \mu \mathrm{mol} / \mathrm{L}, 0.4 \mu \mathrm{mol} / \mathrm{L}, 0.13 \mu \mathrm{mol} / \mathrm{L}, 0.043$ $\mu \mathrm{mol} / \mathrm{L}$ ) at $4^{\circ} \mathrm{C}$ for 2 hours in the dark.

\section{Exposure of DNA to different nanoparticles}

Plasmid pUC18 DNA, at a concentration of $15 \mathrm{ng} / \mu \mathrm{L}$, was incubated with nano- $\mathrm{TiO}_{2}$, fullerenes, MAA-QDs, and octylamine-modified polyacrylic acid-coated CdSe/ZnS QDs (OPA-QDs) at final concentrations of $1.5 \mathrm{mg} / \mathrm{mL}, 1.5 \mathrm{mg} / \mathrm{mL}$, $3.6 \mu \mathrm{mol} / \mathrm{L}, 3 \mu \mathrm{mol} / \mathrm{L}$, respectively, for 2 hours at $4^{\circ} \mathrm{C}$ in the dark, producing a final volume of $20 \mu \mathrm{L}$.

\section{Exposure of DNA to $\mathrm{Cd}$ ions, MAA, or both}

Damages to DNA caused by Cd ions, MAA or a mixture of $\mathrm{Cd}$ ions and MAA were assessed as follows.

MAA: pUC18 DNA, at a concentration of $15 \mathrm{ng} / \mu \mathrm{L}$, was incubated with increasing concentrations of MAA (final concentration, $0.05,0.5,5,50 \mathrm{mmol} / \mathrm{L}$ ) at $4^{\circ} \mathrm{C}$ for 12 hours in the dark, for a final volume of $20 \mu \mathrm{L}$.

Cd ions: pUC18 DNA, at a concentration of $15 \mathrm{ng} / \mu \mathrm{L}$, was incubated with increasing concentrations of $\mathrm{Cd}$ ions (final concentration, $0.5,5,50,500 \mu \mathrm{mol} / \mathrm{L}$ ), at $4^{\circ} \mathrm{C}$ for 12 hours in the dark, for a final volume of $20 \mu \mathrm{L}$.

Cd and MAA: pUC18 DNA, at a concentration of $15 \mathrm{ng} / \mu \mathrm{L}$, was incubated with $\mathrm{Cd}$ ions (final concentration, $500 \mu \mathrm{mol} / \mathrm{L}$ ) and increasing concentrations of MAA (final concentration, $0,5,10,15,25,35,45 \mathrm{mmol} / \mathrm{L}$ ) at $4^{\circ} \mathrm{C}$ for 12 hours in the dark, for a final volume of $20 \mu \mathrm{L}$.

\section{Genetic transformation}

The biological activities of the plasmids were determined from the transformation tests. A variation of the procedure of Cohen was implemented for transformation ${ }^{19}$. Escherichia coli strain DH5 $\alpha$ was cultured with shaking at $37^{\circ} \mathrm{C}$ overnight in Luria-Bertani (LB) medium. Competent cells were prepared by inoculating $1 \mathrm{~mL}$ overnight culture in $100 \mathrm{~mL}$ $\mathrm{LB}$ medium and then grown with shaking at $37^{\circ} \mathrm{C}$ to reach a density of $1 \times 10^{9}$ colony-forming units per $\mathrm{mL}(\mathrm{CFU} / \mathrm{mL})$. The cells were then quickly chilled, centrifuged and washed in $20 \mathrm{~mL} \mathrm{CaCl}_{2}(100 \mathrm{mmol} / \mathrm{L})$, kept cold at $0^{\circ} \mathrm{C}$ for 1 hour, then centrifuged and washed in $5 \mathrm{~mL} \mathrm{CaCl}_{2}$ and further chilled for 30 minutes. Competent cells were dispensed into chilled micro-centrifuge tubes after simply inverting and gently shaking. We added $4.17 \mathrm{ng}(1 \mu \mathrm{L})$ of the DNA sample incubated with nanoparticles to $100 \mu \mathrm{L}$ of $\mathrm{CaCl}_{2}$-treated E. coli $\mathrm{DH} 5 \alpha$ competent cells, and an additional incubation was performed for 30 minutes at $0^{\circ} \mathrm{C}$. The cells were then subjected to a heat pulse at $42^{\circ} \mathrm{C}$ for 90 seconds, kept at $0^{\circ} \mathrm{C}$ for 2 minutes and then plated directly onto a solid LB medium containing $100 \mu \mathrm{g} / \mathrm{mL}$ of ampicillin. ${ }^{19}$ The transformants were counted after 12 to 16 hours of incubation at $37^{\circ} \mathrm{C}$.

For all transformation experiments, transformation efficiency was calculated as CFU per $\mu \mathrm{g}$ plasmid DNA. We regarded the transformation efficiency of untreated plasmid DNA as $100 \%$, and then calculated the residual transformation activity of the incubated plasmid DNA by comparing the transformation efficiency to that of untreated control. The biological effect of nanoparticles on DNA should be confirmed in repeated experiments $(n>3)$. All quantitative data are expressed as the mean \pm standard deviation. The values of the residual transformablities are the averages from three replicate transformation experiments for each sample, and the error bars represent the standard deviations. All data were statistically analyzed. $P$ values less than 0.05 were considered to indicate statistical significance.

In the process of testing, the untreated DNA control must be prepared using the same conditions as the incubated sample. As the final amount of $4.17 \mathrm{ng}(1 \mu \mathrm{L})$ nanoparticlestreated plasmid DNA sample was used to transform $100 \mu \mathrm{L}$ of $\mathrm{CaCl}_{2}$-treated competent $E$. coli strain $\mathrm{DH} 5 \alpha$, the transformation frequency and viability of the competent $E$. coli strain DH5 $\alpha$ treated with 100 -fold diluted nanoparticles should also be monitored to make sure that there was no apparent difference between the nanoparticles-treated and non-treated 
competent E. coli strain DH5 $\alpha$. Additionally, the influence of nanoparticles on the competent $E$. coli strain DH5 $\alpha$ could be avoided by using DNA purification kits.

\section{Preparation of $\mathrm{Cd}$ complexes and ESI-MS measurements}

A mixture of $50 \mathrm{mmol} / \mathrm{L}$ of the mercaptoacetic acid ligand and $50 \mathrm{mmol} / \mathrm{L}$ of cadmium chloride in water was stirred for 30 minutes. Both the solid residue and the supernatant were separated by centrifuging. The $\mathrm{Cd}$ complex solution was obtained by washing the solid residue three times with cool water followed by dissolution in water, and finally filtered off. After processing to remove the intact nanoparticles by centrifuging, the remaining solutions of the QDs samples were also tested for Cd complex by ESI-MS. Data were measured using a LCQ-Advantage MS spectrometer (Thermo Finnigan Inc, New York, NY) in positive ion mode. The flow rate was $0.8 \mathrm{~mL}$ minute ${ }^{-1}$. Injections were carried out at a spray voltage of $4.5 \mathrm{kV}$, a capillary voltage of $4.0 \mathrm{~V}$, and a capillary temperature of $200^{\circ} \mathrm{C}$.

\section{MAA-Cd-DNA binding analysis by fluorescence spectroscopy}

The ethidium bromide (EtBr) fluorescence quenching experiments were carried out by adding 0 to $1 \mathrm{mmol} / \mathrm{L} \mathrm{Cd}-\mathrm{MAA}$ complex into the EtBr bound CT-DNA (0.05 mmol/L) solution in $\mathrm{ddH}_{2} \mathrm{O}(\mathrm{pH}$ 7.0). The mixtures were incubated at room temperature for 30 minutes in the dark. The fluorescence spectra of EB bound to DNA were obtained at an emission wavelength of $605 \mathrm{~nm}$ in the fluorometer.

\section{Circular dichroism measurements}

All CD spectroscopic studies were carried out with a continuous flow of nitrogen purging the polarimeter using a Jasco J-810 automatic recording spectropolarimeter (Jasco, Tokyo, Japan). The measurements were performed at room temperature, using cells with a $1 \mathrm{~cm}$ pathway. The CD spectra of each sample solution were scanned over the range of 320-220 nm, and the buffer background was automatically subtracted. Data were recorded at an interval of $2 \mathrm{~nm}$. The CD spectrum of pUC18 DNA alone $(0.2 \mathrm{mmol} / \mathrm{L})$ was recorded as the control experiment.

\section{Results and discussion Effect of MAA-coated CdSe QDs on the configuration of plasmid DNA}

The damage caused by the MAA-coated CdSe QDs to the configuration of DNA was detected using agarose gel electrophoresis. The incubated plasmid DNA exhibited two bands on the agarose gel. The faster moving band corresponds to the $\mathrm{CCC}$ form, and the slower band corresponds to the OC form. Although DNA nicking could hardly be detected when the plasmid was incubated with low concentrations (0.4 $\mu \mathrm{mol} / \mathrm{L}, 0.13 \mu \mathrm{mol} / \mathrm{L}, 0.043 \mu \mathrm{mol} / \mathrm{L})$ of MAA-QDs (lanes 4-6, Figure 1A), it was evident that the exposure of $833 \mathrm{ng}$ of pUC18 DNA to high concentrations of QDs (3.6 $\mu \mathrm{mol} / \mathrm{L}, 1.2 \mu \mathrm{mol} / \mathrm{L}$ ) at $4{ }^{\circ} \mathrm{C}$ for 2 hours in the dark resulted in DNA nicking (lanes 2-3, Figure 1A). The percentage of the OC form of plasmid DNA reached approximately $59.9 \%$ $\pm 12.8 \%$ at a concentration of $3.6 \mu \mathrm{mol} / \mathrm{L}$ QDs (Figure $1 \mathrm{~B}$ ), which indicated that the MAA-coated CdSe QDs are a potent DNA cleavage agent.

\section{Effect of QDs on the biological potential of plasmid DNA}

The biological activity of DNA may be lost due to the DNA lesions, ${ }^{20}$ and the biological effects on DNA molecules could be reflected sufficiently by the reduction in the transformation capacity of the plasmid DNA. ${ }^{21}$ Thus, the DNA quality of plasmids pUC18 incubated with nanoparticles could be tested by transformation with $E$. coli strain $\mathrm{DH} 5 \alpha$, and the residual transformation activity used as a parameter to evaluate the biological damage to plasmid DNA that was incubated with MAA-QDs (3.6 0.043 $\mu \mathrm{mol} / \mathrm{L})$. After incubation with different concentrations of MAA-QDs $(3.6 \mu \mathrm{mol} / \mathrm{L}$, $1.2 \mu \mathrm{mol} / \mathrm{L}, 0.4 \mu \mathrm{mol} / \mathrm{L}, 0.13 \mu \mathrm{mol} / \mathrm{L}, 0.043 \mu \mathrm{mol} / \mathrm{L}$ ) at $4{ }^{\circ} \mathrm{C}$ for 2 hours in the dark, a dose-dependent decrease in the residual transformation activity of plasmid DNA was observed (from $80.7 \% \pm 12.8 \%$ to $13.6 \% \pm 0.8 \%$, Figure $1 \mathrm{C}$ ). As shown in Figure 1C, significant damage to the DNA was observed when the DNA was treated with $3.6 \mu \mathrm{mol} / \mathrm{L}(P<0.001)$, $1.2 \mu \mathrm{mol} / \mathrm{L}(P<0.001), 0.4 \mu \mathrm{mol} / \mathrm{L}(P<0.01)$, and 0.13 $\mu \mathrm{mol} / \mathrm{L}(P<0.05)$ of QDs. The damage to the DNA was not statistically significant when treated with QDs at the concentration of $0.043 \mu \mathrm{mol} / \mathrm{L}$. In contrast to previous data on the potency of QDs to damage DNA (Figure 1B), the statistical analysis of the residual transformation activity (Figure 1C) could show better accuracy for the evaluation of the genetic toxicity of nanoparticles.

Furthermore, biological effects of nano- $\mathrm{TiO}_{2}$, fullerenes, and octylamine-modified polyacrylic acid-coated $\mathrm{CdSe} / \mathrm{ZnS}$ QDs (OPA-QDs) were also investigated using the transformation assay. DNA qualities of plasmids pUC18 incubated with nano- $\mathrm{TiO}_{2}(1.5 \mathrm{mg} / \mathrm{mL})$, fullerenes $(1.5 \mathrm{mg} / \mathrm{mL})$ and OPA-QDs $(3 \mu \mathrm{mol} / \mathrm{L})$ for 2 hours at $4^{\circ} \mathrm{C}$ in the dark were tested by transformation with $E$. coli strain $\mathrm{DH} 5 \alpha$. The results 


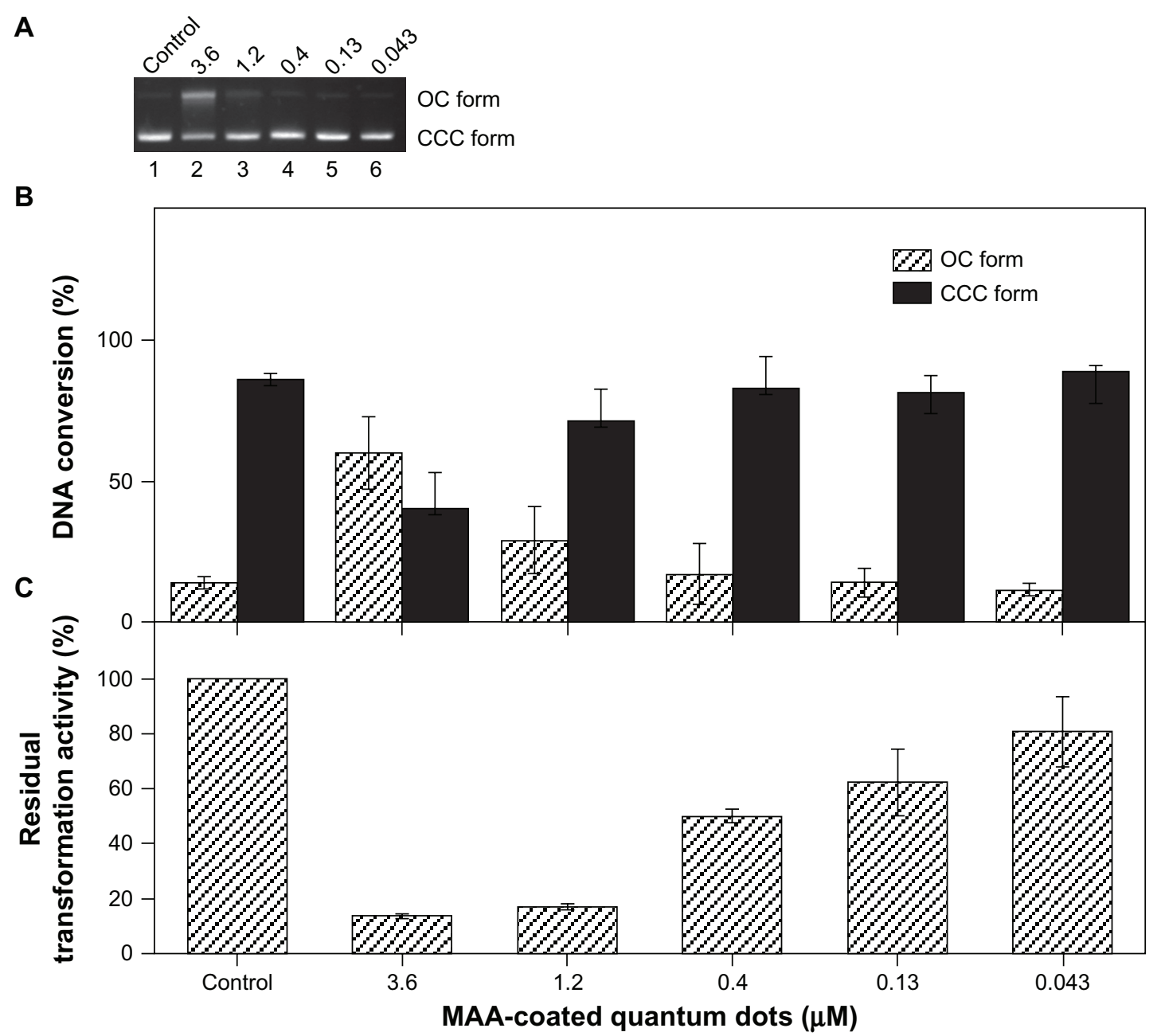

Figure I Effects of MAA-coated CdSe QDs on the plasmid DNA. (A) Electrophoresis in 1\% agarose gel of pUCI8 DNA (I50 ng per sample) incubated for 2 hours at $4^{\circ} \mathrm{C}$ in the dark with QDs. Lane I: pUCl8 DNA only; lanes 2-6: pUCl8 DNA incubated with different concentrations of QDs (3.6, I.2, 0.4, $\left.0.13,0.043 \mu \mathrm{mol} / \mathrm{L}\right)$. (B) DNA quality of plasmids pUCI8 incubated with different concentrations of QDs $(3.6,1.2,0.4,0.13,0.043 \mu \mathrm{mol} / \mathrm{L})$ for 2 hours at $4^{\circ} \mathrm{C}$ in the dark was tested by transformation with Escherichia coli strain $\mathrm{DH} 5 \alpha$. (C) Scanning densitometry results of three replicate experiments for each sample, with the error bars representing the standard deviations.

Abbreviations: OC, opened circular; CCC, covalently closed circular; MAA, mercaptoacetic acid; QDs, quantum dots.

demonstrated that there is no significant difference between the incubated and non-incubated plasmids in transformation activity ( $P>0.05$, Figure 2$)$. Hence, in the present study, despite the different mechanisms of DNA damage that are caused by nanoparticles, a quantitative analysis method was well established and the effects of damage from most nanoparticles on DNA could be evaluated in the plasmid-based noncellular system.

\section{Primary toxin in the solution of MAA-coated CdSe QDs}

In previous work, high levels of free cadmium $(1.1 \mathrm{mmol} / \mathrm{L})$ could be found in $0.25 \mathrm{mg} / \mathrm{mL}$ solutions of QDs because of the degradation of the QDs. ${ }^{10}$ DNA strand breaks, arising from the photogenerated free radicals or the generated surface oxide, ${ }^{22,23}$ have been reported; however, the direct interaction between DNA and the chemical composition of QDs currently remains unclear. To determine whether cadmium or MAA is capable of inducing damage to DNA, the effects of MAA, $\mathrm{Cd}^{2+}$ and the combination of both on DNA nicking were studied. Because incubations of plasmid DNA with $0.5,5,50,500 \mu \mathrm{mol} / \mathrm{L} \mathrm{CdCl}_{2}$ (lanes 3-6, Figure 3) at $4^{\circ} \mathrm{C}$ for 12 hours in the dark did not cause DNA nicking, it is evident that the DNA nicking caused by QDs in the dark was not due to cadmium. Additionally, when the DNA was incubated with increasing concentrations of MAA, the gel electrophoresis bands became smeared without the expected DNA nicking (lanes 8-10, Figure 3). However, a dose-dependent increase in DNA nicking was observed when $300 \mathrm{ng}$ of the $\mathrm{pUC} 18$ plasmid DNA was incubated with mixtures of $\mathrm{Cd}^{2+}(0.5 \mathrm{mmol} / \mathrm{L})$ and MAA $(0,5,10,15,25,35 \mathrm{mmol} / \mathrm{L})$ at $4^{\circ} \mathrm{C}$ for 12 hours in the dark (lanes 3-8, Figure 4). 


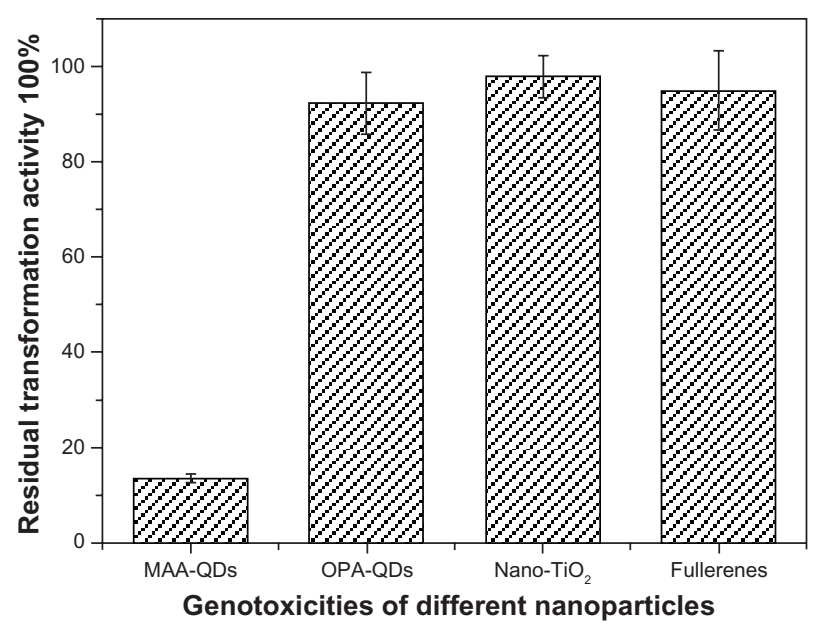

Figure 2 Effects of different nanoparticles on the transformablities of plasmid DNA. Notes: DNA qualities of plasmids pUCl8 incubated with nano- $\mathrm{TiO}_{2}(1.5 \mathrm{mg} / \mathrm{mL})$, fullerenes $(1.5 \mathrm{mg} / \mathrm{mL})$, MAA-QDs $(3.6 \mu \mathrm{mol} / \mathrm{L})$ and OPA-QDs $(3 \mu \mathrm{mol} / \mathrm{L})$ for 2 hours at $4^{\circ} \mathrm{C}$ in the dark were tested by transformation with Escherichia coli strain $\mathrm{DH} 5 \alpha$. There is no significant difference between the incubated and non-incubated plasmids in transformation activity when plasmids were incubated with nano- $\mathrm{TiO}_{2}$, fullerenes, and OPA-QDs $(P>0.05)$, respectively.

Abbreviations: MAA-QDs, mercaptoacetic acid-coated quantum dots; OPA-QDs, octylamine-modified polyacrylic acid-coated quantum dots.

Electrospray ionization mass spectrometry (ESI-MS) was performed to find the primary toxin in the mixture of $\mathrm{Cd}^{2+}$ and MAA. As a chelating agent, the ligand mercaptoacetic acid forms a $\mathrm{CdL}_{2}$ complex with cadmium chloride (Figure $5 \mathrm{~A}$ ) in the mixture of $\mathrm{Cd}$ and MAA. The $\mathrm{Cd}$ complex with mercaptoacetic acid could also be formed in the solution of MAA-coated CdSe QDs (Figure 5B). When incubated with pUC18 DNA, the Cd-MAA complex had a nicking effect on the plasmid DNA (data not shown). Furthermore, the configurational damage to plasmid pUC18 that was treated with non-sulfur compound coated QDs (OPA-QDs) was monitored, and no detectable DNA nicking was observed (data not shown). The biological damage to plasmid pUC18 treated with OPA-QDs was also monitored. The data indicated that the DNA was only slightly damaged when incubated with non-sulfur compound

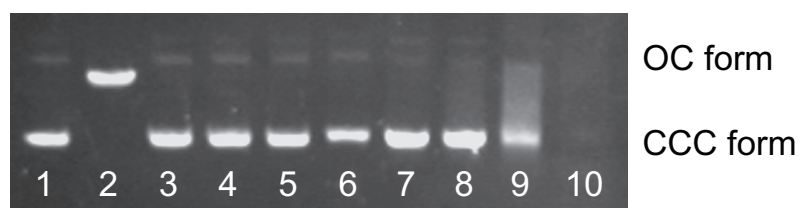

Figure 3 Effect of $\mathrm{Cd}^{2+}$ or MAA on the configuration of plasmid DNA.

Notes: Electrophoresis in 1\% agarose gel of pUCI8 DNA (I50 ng per sample) incubated for 12 hours at $4{ }^{\circ} \mathrm{C}$ in the dark with increasing concentrations of $\mathrm{Cd}^{2+}$ or with increasing concentrations of MAA. Lane I: pUCI8 DNA only; lane 2: pUCI8 DNA digested by Hind III; lanes 3-6: pUCI8 DNA incubated with 0.5, 5, 50, $500 \mu \mathrm{mol} / \mathrm{L}$ Cd ions; lanes 7-10: pUCI8 DNA incubated with 0.05, 0.5, 5, $50 \mathrm{mmol} / \mathrm{L}$ MAA. DNA smear caused by MAA was observed in lanes $8-10$, and the PUCI8 plasmid DNA in lane 10 was completely degraded by MAA.

Abbreviations: OC, opened circular; CCC, covalently closed circular; MAA, mercaptoacetic acid. coated QDs ( $P>0.05$, Figure 2$)$. Thus, in the case of MAAcoated CdSe QDs, we suggest that the DNA damage caused by MAA-QDs is a co-effect of the MAA and cadmium and that the $\mathrm{Cd}\left(\mathrm{SCH}_{2} \mathrm{COOH}\right)_{2}$ complexes may be related to the DNA nicking. To the best of our understanding, the formation of the Cd-MAA complex in the solution of QDs and its effect on the secondary structure of DNA have not been comprehensively pursued in a systematic manner.

\section{Interaction between DNA and the cadmium-MAA complex}

To gain a deeper insight into the DNA damage induced by the MAA-QDs, the direct interactions between DNA and the cadmium-MAA complex were investigated. DNA binding is the critical step for DNA damage in most cases. Therefore, fluorescence, circular dichroism spectroscopy and transformation assays were performed to investigate the binding of the ligand, MAA, and its complex, Cd-MAA, to DNA.

\section{Fluorescence spectroscopy}

Ethidium bromide (EtBr) fluorescence displacement experiments were employed to further investigate the interaction mode between the cadmium complex and DNA. The assay was based on the theory that a highly fluorescent complex could be formed between native DNA and the intercalating agent, EtBr. Using CT-DNA as a model, the damage to DNA caused by the cadmium complex was explored using the fluorescence method. The binding of the cadmium complex to CT-DNA was studied by evaluating the fluorescence emission intensity of the EtBr-DNA system following addition of the compound. In our experiment, as illustrated in Figure 6, the fluorescence intensity at $605 \mathrm{~nm}$ of EtBr bound to DNA showed no significant decreasing trend with increasing concentrations of the cadmium complex, which is suggestive of a nonintercalative mode of DNA binding. By considering the fluorescence intensity value of EtBr-DNA complexes as equal to $100 \%$, the extent of fluorescence quenching with the Cd-MAA complex has been determined to be equal to $20.21 \%$ at the highest molar ratio of 1:20. Furthermore, similar fluorescence quenching effects of EtBr bound to DNA have been observed for the addition of several groove-binding compounds, including distamycin A, methyl thiophanate, and amsacrine. ${ }^{24-26}$ This observation leads us to suggest that the cadmium complex may interact with DNA through the groove-binding mode. ${ }^{27}$

\section{Circular dichroism studies}

Circular dichroism is a powerful technique to assess whether nucleic acids undergo conformational changes during 
A
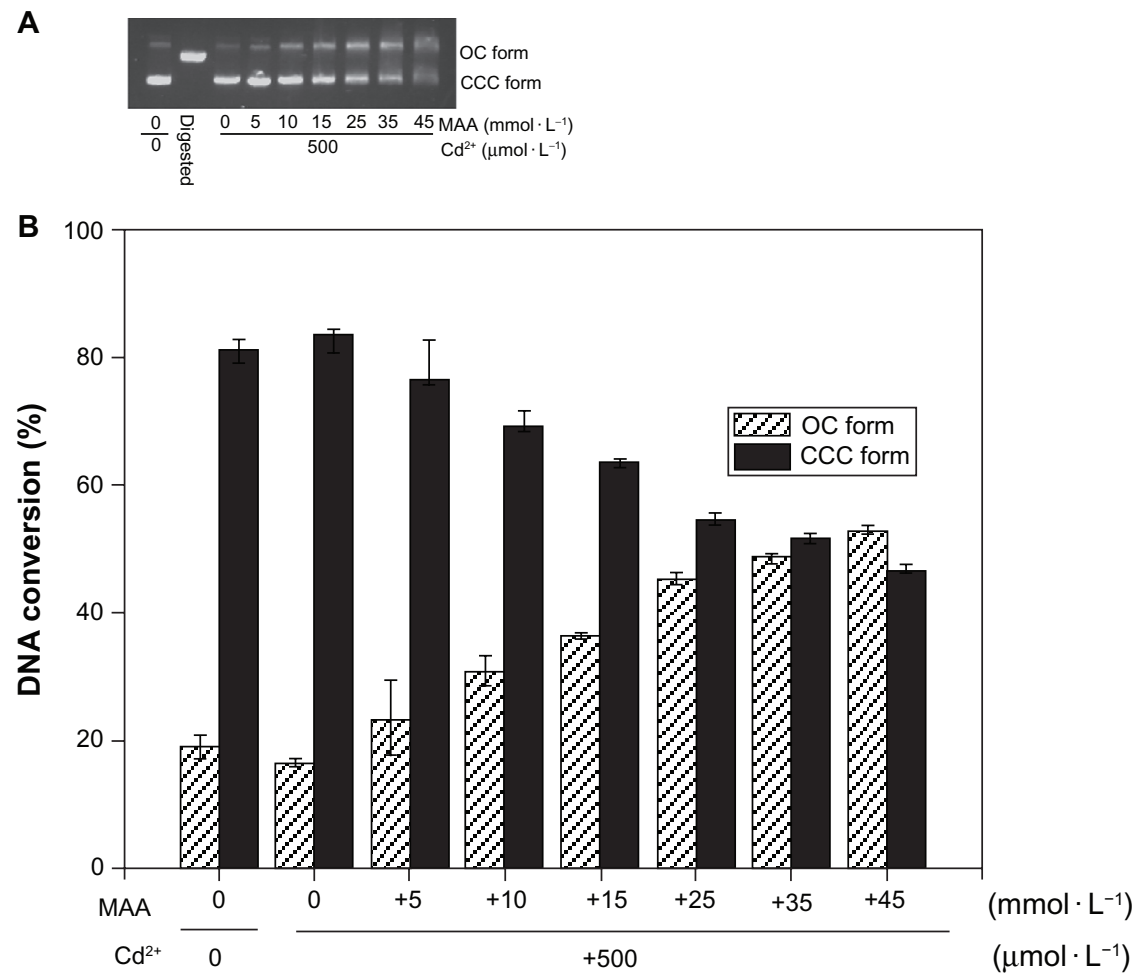

Figure 4 Co-effect of $C \mathrm{~d}^{2+}$ and MAA on the configuration of plasmid DNA. (A) Electrophoresis in $1 \%$ agarose gel of pUCI8 DNA ( 150 ng per sample) incubated with Cd $\mathrm{d}^{2+}$ in the presence of increasing MAA concentrations for 12 hours at $4^{\circ} \mathrm{C}$ in the dark. Lane I: pUCI8 DNA only; lane 2: pUCI8 DNA digested by Hind III; lanes 3-9: pUCl8 DNA incubated with mixtures of $\mathrm{Cd}^{2+}(500 \mu \mathrm{mol} / \mathrm{L})$ and $0,5,10,15,25,35,45 \mathrm{mmol} / \mathrm{L}$ MAA. (B) Scanning densitometry results of three replicate experiments for each sample, with the error bars representing the standard deviations.

Abbreviations: OC, opened circular; CCC, covalently closed circular; MAA, mercaptoacetic acid.
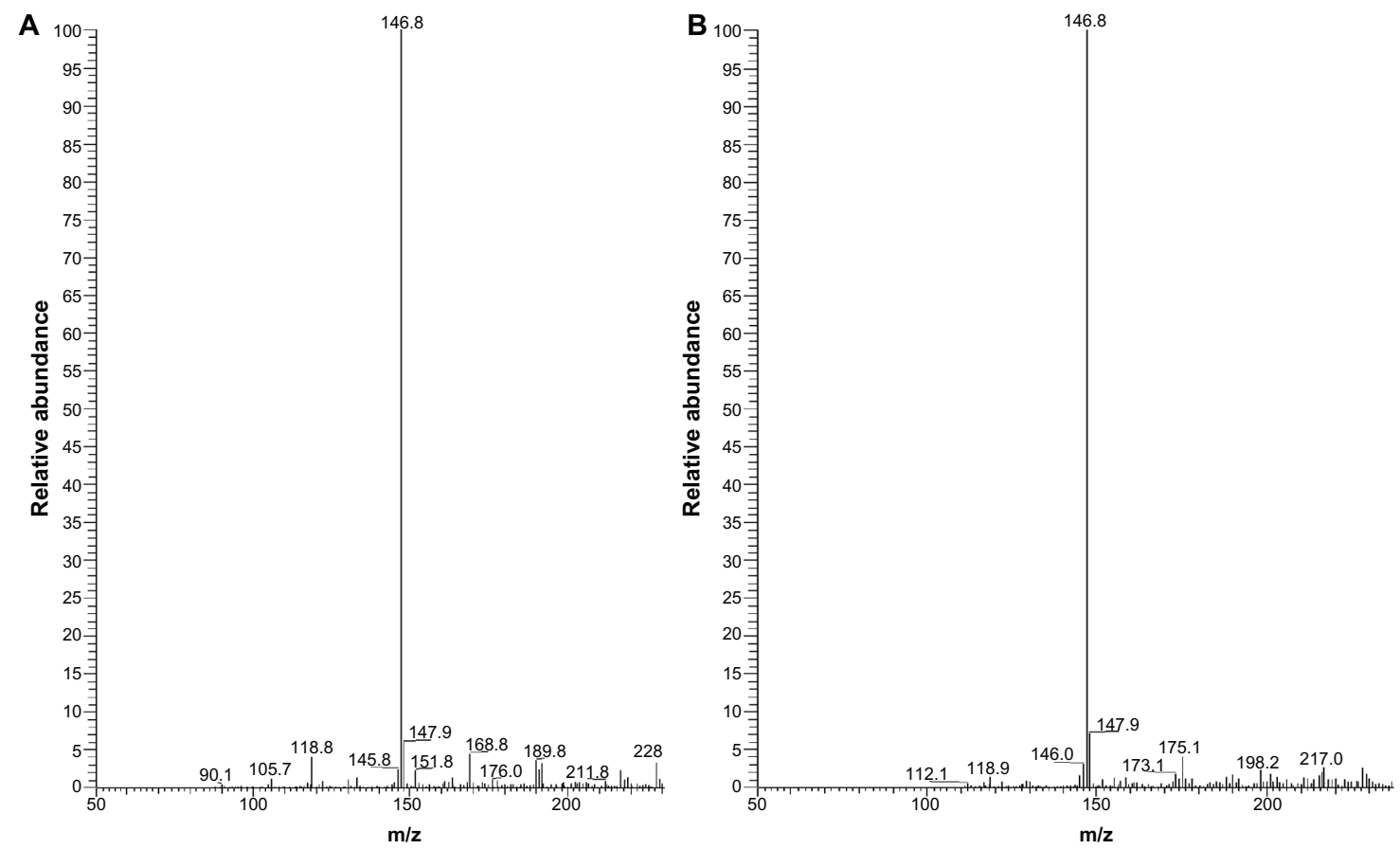

Figure $5 \mathrm{ESI}$ mass spectra of $\mathrm{Cd}\left(\mathrm{SCH}_{2} \mathrm{COOH}\right)_{2}$ complex. Each peak represents an ion having a specific mass-to-charge ratio $(\mathrm{m} / \mathrm{z})$, and the height of the peak indicates the relative abundance. The base peak in the mass spectrum, corresponding to the ion which has the greatest intensity, is set to $100 \%$ relative abundance. (A) The base peak at $\mathrm{m} / \mathrm{z} \mid 46.8$ suggests the greatest intensity of $\mathrm{Cd}\left(\mathrm{SCH}_{2} \mathrm{COOH}\right)_{2}$ in the mixture of $\mathrm{Cd}$ and MAA. (B) The base peak at $\mathrm{m} / \mathrm{z}$ I46.8 suggests the greatest intensity of $\mathrm{Cd}\left(\mathrm{SCH}_{2} \mathrm{COOH}\right)_{2}$ in the solution of MAA-coated $\mathrm{CdSe} \mathrm{QDs} . \mathrm{Cd}\left(\mathrm{SCH}_{2} \mathrm{COOH}\right)_{2}$ appears to be the primary toxin as no other ions were present above $10 \%$ relative abundance in either of the solutions.

Abbreviations: ESI mass, electrospray ionization mass; MAA, mercaptoacetic acid. 


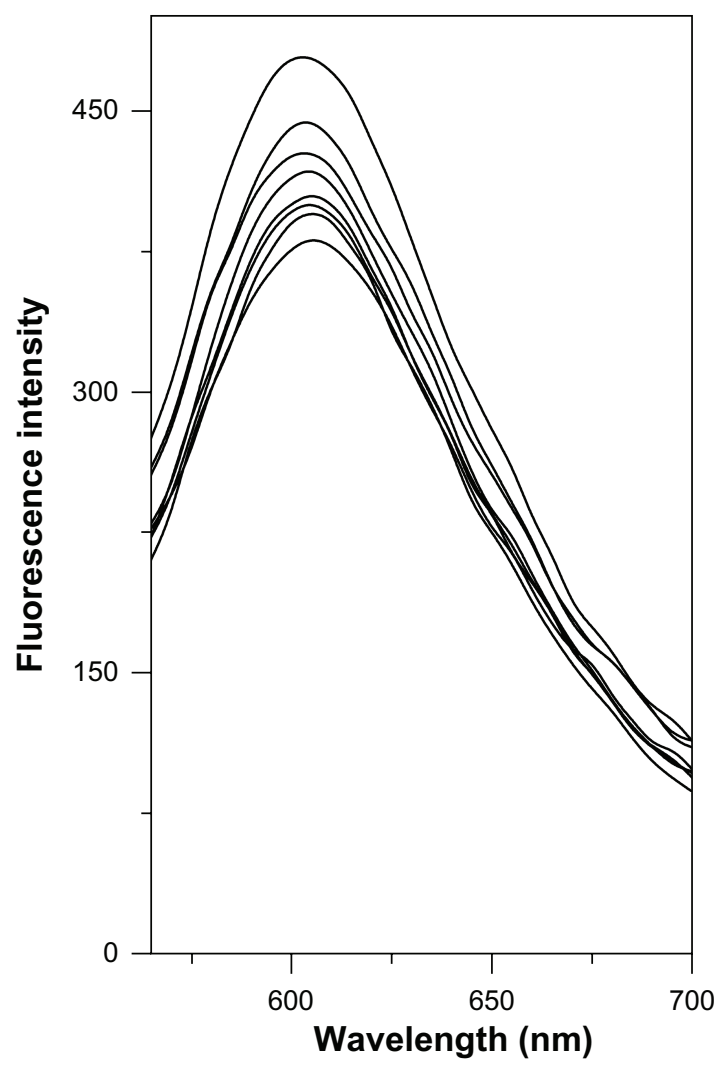

Figure 6 Competitive displacement of intercalating dye EtBr from EtBr-CT-DNA complex by the Cd-MAA complex.

Notes: Curves from top to bottom: $\mathrm{EtBr}(10 \mu \mathrm{mol} / \mathrm{L})+C T$-DNA $(50 \mu \mathrm{mol} / \mathrm{L})$; $\mathrm{EtBr}(10 \mu \mathrm{mol} / \mathrm{L})+\mathrm{CT}-\mathrm{DNA}(50 \mu \mathrm{mol} / \mathrm{L})+$ cadmium complex $(10,20,30,40,50$, $100,1000 \mu \mathrm{mol} / \mathrm{L})$. Fluorescence was monitored at $605 \mathrm{~nm}$ using an excitation wavelength of $518 \mathrm{~nm}$.

Abbreviations: $\mathrm{EtBr}$, ethidium bromide; CT-DNA, Calf-thymus DNA; Cd-MAA, cadmium-mercaptoacetic acid.

drug-DNA interactions, as the bands arising from base stacking $(275 \mathrm{~nm})$ and from right-handed helicity $(248 \mathrm{~nm})$ are quite sensitive to the mode of DNA interactions with small molecules. ${ }^{28,29}$ In the CD spectra of pUC18 DNA that was treated with MAA and Cd-MAA (compound:DNA $=0.4: 1$ ) (Figure 7), the positive $(275 \mathrm{~nm})$ band decreased in intensity with the addition of the compound, while the negative ( $245 \mathrm{~nm}$ ) band exhibited no significant change. This suggests that MAA and Cd-MAA can unwind the DNA helix and lead to the loss of helicity. ${ }^{30,31}$ The larger decrease in the $\mathrm{CD}$ band intensity, caused by Cd-MAA compared to MAA at the same concentration, implies that $\mathrm{Cd}-\mathrm{MAA}$ is more effective than MAA in perturbing the secondary structure of DNA.

\section{High GC content DNA shows resistance to Cd-MAA complex}

Groove-binding compounds, such as the $\mathrm{Cu}-$ methyl thiophanate complex and amsacrine, prefer binding to the AT-rich region or to poly(dA-dT). ${ }^{24,26,32}$ Therefore, DNA containing higher contents of AT could receive more damage

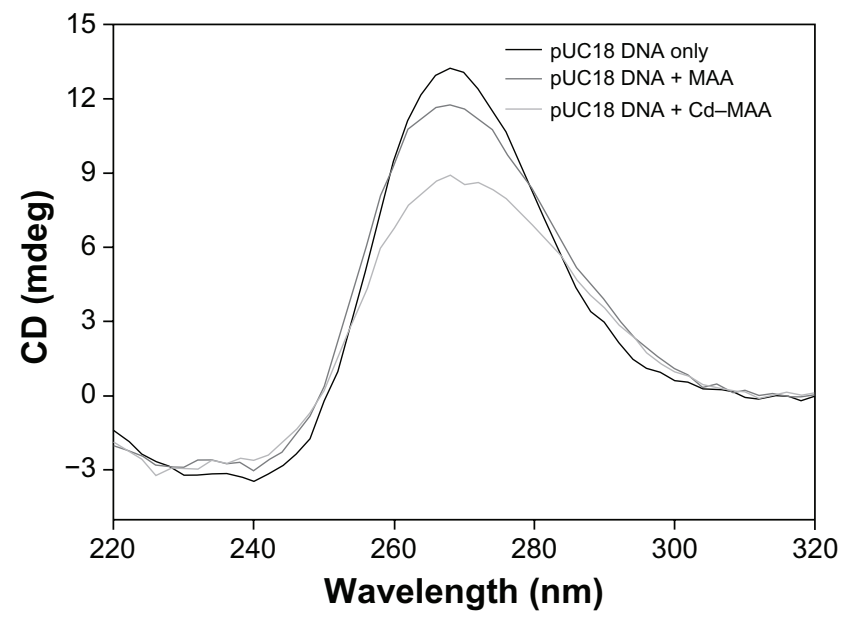

Figure 7 CD spectra of pUCI8 DNA.

Notes: The interactions of pUCI8 DNA with MAA and Cd-MAA were at a ratio of compound:DNA = 0.4. All the spectra were recorded in Tris- $\mathrm{HCl}$ buffer, $\mathrm{pH}$ 7.0.

Abbreviations: CD, circular dichroism; MAA, mercaptoacetic acid; Cd-MAA, cadmium-mercaptoacetic acid.

from the groove-binding compounds. To examine whether the Cd-MAA complex is a groove-binding compound, experiments evaluating the biological damage to plasmids with different GC percentage $(41.5 \%, 59.55 \%)$ were performed. After incubation with the same concentration of MAA-QDs $(3.6 \mu \mathrm{mol} / \mathrm{L})$ at $4{ }^{\circ} \mathrm{C}$ for 12 hours in the dark, a significantly higher residual transformation activity of the high $\mathrm{GC} \%$ plasmid was observed compared to the low $\mathrm{GC} \%$ one $(P<0.001$, Figure 8$)$, indicating that the Cd-MAA complex is a groove-binding compound and has an innate tendency to damage plasmids with high content of AT.

In conclusion, dose-dependent DNA damage caused by MAA-coated CdSe-core QDs at $4^{\circ} \mathrm{C}$ in the dark has been shown in this paper. We attribute the effects of DNA damage to a coeffect due to the chemical components in the QDs solution, which could be linked to the instability of QDs. A novel mechanism, which may be generally applicable or only apply to this system, was demonstrated in this paper and shows that the Cd-MAA complex may contribute to the DNA nicking and the decrease of biological activity of DNA. The Cd-MAA complex in the solution of MAA-QDs may interact with DNA through the groove-binding mode, and furthermore, the Cd-MAA complex has an innate tendency to damage plasmids with a high AT content or an AT-rich region. Although the damage mechanism remains unclear, considering the loose base-pairing of thymine and adenine, it was understandable that the Cd-MAA complex can bind with AT-rich region and then induce DNA damage with facility. Furthermore, these findings serve to suggest parameters to minimize the genotoxicity of QDs in biological applications: storing QDs uncoated, replacing the sulfur 


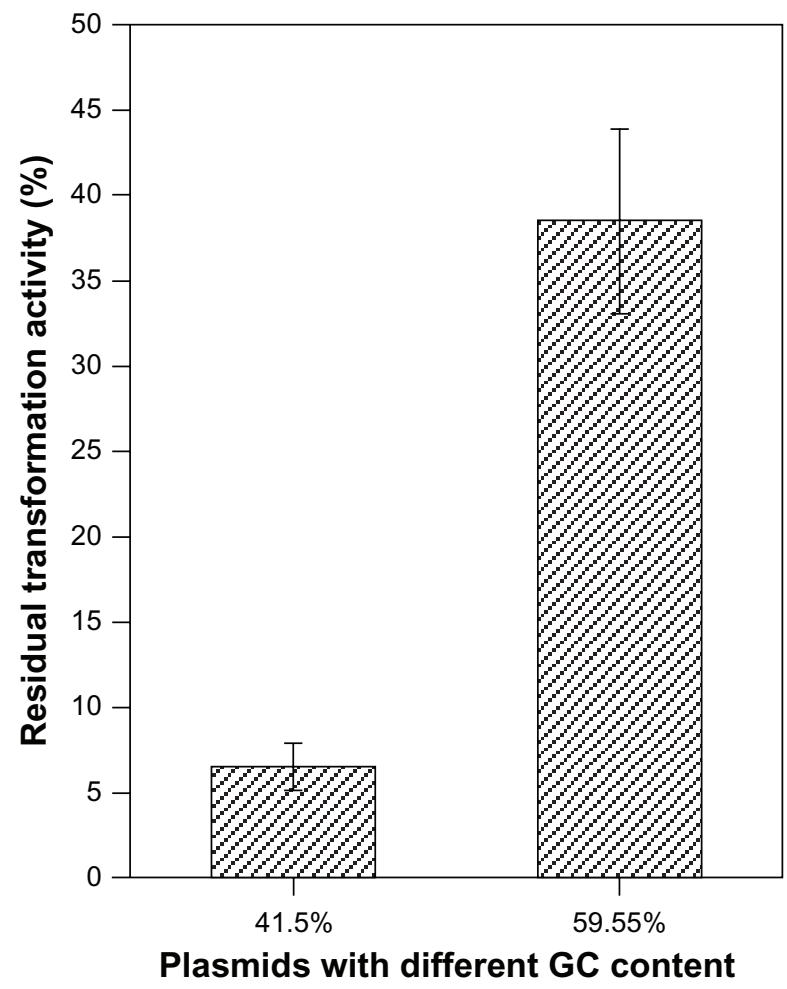

Figure 8 Effects of QDs on the plasmids with different GC contents. Notes: Plasmids with the same size and dose but contained different GC contents $(41.5 \%, 59.55 \%)$ and were incubated with MAA-coated CdSe QDs $(3 \mu \mathrm{mol} / \mathrm{L})$ for 2 hours at $4^{\circ} \mathrm{C}$ in the dark. $P<0.001$.

Abbreviations: QDs, quantum dots; GC content, guanine + cytosine content.

compound coating, and using QDs with sulfur compound coating immediately after coated if absolutely necessary.

The evaluation of biosafety is considered to be an essential requirement in the biological applications of nanoparticles. However, the scarcity of quantitative analysis methods has become an obstacle to gaining more information about the basic concerns of DNA damage induced by nanoparticles. Therefore, the plasmid transformation assay, which is a functional test, was performed to evaluate the genotoxic damage caused by nanoparticles.

\section{Acknowledgments}

This work was supported by the National Natural Science Foundation of China (20677044, 30971573), the Science Fund for Creative Research Groups of NSFC (20621502, 20921062), National High-tech R\&D Program of China (863 Program) (2007 AA06Z407), the Fundamental Research Funds for the Central Universities (3081001), and the National Fund for Fostering Talents of Basic Science (J1103513). We would also like to thank Dr. Yong Li (Wuhan University), Dr. Yan Zhang (Wuhan University) and Dr. Jingwei Gao (Wuhan University) for technical assistance and helpful discussion.

\section{Disclosure}

The authors report no conflicts of interest in this work.

\section{References}

1. Bruchez M Jr, Moronne M, Gin P, Weiss S, Alivisatos AP. Semiconductor nanocrystals as fluorescent biological labels. Science. 1998;281(5385):2013-2016.

2. Chan WC, Nie S. Quantum dot bioconjugates for ultrasensitive nonisotopic detection. Science. 1998;281(5385):2016-2018.

3. Chan WC, Maxwell DJ, Gao X, Bailey RE, Han M, Nie S. Luminescent quantum dots for multiplexed biological detection and imaging. Curr Opin Biotechnol. 2002;13(1):40-46.

4. Dubertret B, Skourides P, Norris DJ, Noireaux V, Brivanlou AH, Libchaber A. In vivo imaging of quantum dots encapsulated in phospholipid micelles. Science. 2002;298(5599):1759-1762.

5. Gao X, Cui Y, Levenson RM, Chung LW, Nie S. In vivo cancer targeting and imaging with semiconductor quantum dots. Nat Biotechnol. 2004;22(8):969-976.

6. Wu X, Liu H, Liu J, et al. Immunofluorescent labeling of cancer marker Her2 and other cellular targets with semiconductor quantum dots. Nat Biotechnol. 2003;21(1):41-46.

7. Arya H, Kaul Z, Wadhwa R, Taira K, Hirano T, Kaul SC. Quantum dots in bio-imaging: Revolution by the small. Biochem Biophys Res Commun. 2005;329(4):1173-1177.

8. Rudge SR, Kurtz TL, Vessely CR, Catterall LG, Williamson DL. Preparation, characterization, and performance of magnetic ironcarbon composite microparticles for chemotherapy. Biomaterials. 2000;21(14):1411-1420.

9. Wu Y, Li X, Steel D, Gammon D, Sham LJ. Coherent optical control of semiconductor quantum dots for quantum information processing. Physica E Low Dimens Syst Nanostruct. 2004;25(2-3):242-248.

10. Derfus AM, Chan WCW, Bhatia SN. Probing the cytotoxicity of semiconductor quantum dots. Nano Lett. 2004;4(1):11-18.

11. Hoshino A, Fujioka K, Oku T, et al. Physicochemical properties and cellular toxicity of nanocrystal quantum dots depend on their surface modification. Nano Lett. 2004;4(11):2163-2169.

12. Yu WW, Chang E, Drezek R, Colvin VL. Water-soluble quantum dots for biomedical applications. Biochem Biophys Res Commun. 2006;348(3):781-786.

13. Aldana J, Wang YA, Peng X. Photochemical instability of CdSe nanocrystals coated by hydrophilic thiols. $\mathrm{J}$ Am Chem Soc. 2001;123(36):8844-8850

14. Zheng Y, Gao S, Ying J. Synthesis and cell-imaging applications of glutathione-capped CdTe quantum dots. Adv Mater. 2007;19(3):376-380.

15. Helbig K, Grosse C, Nies DH. Cadmium toxicity in glutathione mutants of Escherichia coli. J Bacteriol. 2008;190(15):5439-5454.

16. Müller T, Schuckelt R, Jaenicke L. Cadmium/zinc-metallothionein induces DNA strand breaks in vitro. Arch Toxicol. 1991;65(1):20-26.

17. Crisponi G, Diaz A, Nurchi VM, Pivetta T, Tapia Estevez MJ. Equilibrium study on $\mathrm{Cd}(\mathrm{II})$ and $\mathrm{Zn}(\mathrm{II})$ chelates of mercapto carboxylic acids. Polyhedron. 2002;21(14-15):1319-1327.

18. Wu SM, Zhao X, Zhang ZL, et al. Quantum-dot-labeled DNA probes for fluorescence in situ hybridization (FISH) in the microorganism Escherichia coli. Chemphyschem. 2006;7(5):1062-1067.

19. Cohen SN, Chang AC, Hsu L. Nonchromosomal antibiotic resistance in bacteria: genetic transformation of Escherichia coli by R-factor DNA. Proc Natl Acad Sci U S A. 1972;69(8):2110-2114.

20. Otoshi E, Yagi T, Mori T, et al. Respective roles of cyclobutane pyrimidine dimers, (6-4)photoproducts, and minor photoproducts in ultraviolet mutagenesis of repair-deficient xeroderma pigmentosum A cells. Cancer Res. 2000;60(6):1729-1735.

21. Romanowski G, Lorenz MG, Wackernagel W. Use of polymerase chain reaction and electroporation of Escherichia coli to monitor the persistence of extracellular plasmid DNA introduced into natural soils Appl Environ Microbiol. 1993;59(10):3438-3446. 
22. Anas A, Akita H, Harashima H, Itoh T, Ishikawa M, Biju V. Photosensitized breakage and damage of DNA by CdSe-ZnS quantum dots. J Phys Chem B. 2008;112(32):10005-10011.

23. Green M, Howman E. Semiconductor quantum dots and free radical induced DNA nicking. Chem Commun (Camb). 2005;(1):121-123.

24. Baguley BC, Le Bret M. Quenching of DNA-ethidium fluorescence by amsacrine and other antitumor agents: a possible electron-transfer effect. Biochemistry. 1984;23(5):937-943.

25. Nelson SM, Ferguson LR, Denny WA. Non-covalent ligand/ DNA interactions: minor groove binding agents. Mutat Res. 2007; 623(1-2):24-40.

26. Saquib Q, Al-Khedhairy AA, Alarifi SA, Dutta S, Dasgupta S, Musarrat J. Methyl thiophanate as a DNA minor groove binder produces MT-Cu(II)-DNA ternary complex preferably with AT rich region for initiation of DNA damage. Int J Biol Macromol. 2010;47(1): $68-75$.

27. Boger DL, Fink BE, Brunette SR, Tse WC, Hedrick MP. A simple, high-resolution method for establishing DNA binding affinity and sequence selectivity. J Am Chem Soc. 2001;123(25):5878-5891.
28. Lakowicz JR, Weber G. Quenching of fluorescence by oxygen. Probe for structural fluctuations in macromolecules. Biochemistry. 1973;12(21):4161-4170.

29. Uma MP, Palaniandavar M. DNA binding and cleavage properties of certain tetrammine ruthenium(II) complexes of modified 1,10phenanthrolines - effect of hydrogen-bonding on DNA-binding affinity. J Inorg Biochem. 2004;98(2):219-230.

30. Pasternack RF. Circular dichroism and the interactions of water soluble porphyrins with DNA. Chirality. 2003;15(4):329-332.

31. Dalgleish DG, Feil MC, Peacocke AR. The circular dichroism of complexes of 2,7-Di-tertiary-butyl proflavine with DNA. Biopolymers. 1972;11(12):2415-2422.

32. Bourdouxhe-Housiaux C, Colson P, Houssier C, Waring MJ, Bailly C. Interaction of a DNA-threading netropsin-amsacrine combilexin with DNA and chromatin? Biochemistry. 1996;35(14):4251-4264.
International Journal of Nanomedicine

\section{Publish your work in this journal}

The International Journal of Nanomedicine is an international, peerreviewed journal focusing on the application of nanotechnology in diagnostics, therapeutics, and drug delivery systems throughout the biomedical field. This journal is indexed on PubMed Central, MedLine, CAS, SciSearch $\AA$, Current Contents ${ }^{\circledR} /$ Clinical Medicine,

\section{Dovepress}

Journal Citation Reports/Science Edition, EMBase, Scopus and the Elsevier Bibliographic databases. The manuscript management system is completely online and includes a very quick and fair peer-review system, which is all easy to use. Visit http://www.dovepress.com/ testimonials.php to read real quotes from published authors. 